\title{
Low and High Risk Human Papillomavirus in the Oral Mucosa of Mexican Women with Genital Papillomavirus
}

\author{
Ana María Fernández ${ }^{1 *}$, Dora Rosete ${ }^{2}$, Sergio Pedraza ${ }^{3}$, Fidencio Mejía $^{2}$, José Delgado ${ }^{4}$, \\ María Eugenia Manjarrez ${ }^{2}$ \\ ${ }^{1}$ Microbiology and Parasitology Department, Medicine Faculty, National Autonomous \\ University of Mexico (UNAM), Mexico City, Mexico \\ ${ }^{2}$ Virology Research Department, National Institute of Respiratory Disease (INER), México City, Mexico \\ ${ }^{3}$ Spanish Hospital, Mexico City, Mexico \\ ${ }^{4}$ Experimental Medicine Department, Medicine Faculty, National Autonomous \\ University of Mexico (UNAM), Mexico City, Mexico \\ Email: "presas@unam.mx, dorosete67@yahoo.com.mx,drspedrazab@hotmail.com, biolfimene@yahoo.com.mx, \\ ferd@unam.mx, e_manjarrez@yahoo.com,presas@unam.mx
}

Received January 13, 2013; revised February 22, 2013; accepted March 1, 2013

\begin{abstract}
Background: Human papillomaviruses (HPV) are implicated in cervical cancer and, recently in oral cancer. In Mexico, there are few studies on oral cancer, therefore the interest in identifying the HPV frequency of low and high risk in samples of the oral and cervical cavities, and determining some risk factors. Objective: To determine the frequency of high and low risk HPV infection in the oral cavity of women with cervical HPV, and to correlate the infection site with risk factors. Materials and Methods: Eighteen female patients between 24 and 53 years, with antecedents of genital HPV infection were included. Both samples of oral cavity and cervix were obtained. DNA extraction from the epithelial cells was performed using the Qiagen kit. PCR was done and the amplicon was observed in $2 \%$ agarose gels stained with ethidium bromide. A correlation of HPV infection and risk factors was done. Results: HPV-DNA was detected in the $67 \%$ of both samples. The frequency of oral and cervix low risk HPV-DNA was $50 \%$, while high risk HPV-DNA in oral cavity was detected in $17 \%$, and $39 \%$ in the cervix. The study of the risk factors involved in HPV infection showed that the participants had the habits of smoking $39 \%$; alcohol drinking $28 \%$; and $78 \%$ oral sex. Conclusion: The results showed a high frequency of HPV (67\%) infection in the oral and genital mucosas, suggesting that patient's habits could contribute to the infection; the presence of HPV in the oral mucosa may act as reservoir for new HPV infections.
\end{abstract}

Keywords: Human Papillomaviruses (HPV); HPV-DNA; Qiagen Kit

\section{Introduction}

The human papillomavirus (HPV) infection can be grouped into cutaneous and mucosotropic types. The mucosotropic HPVs are typically found in the anogenital mucosa and oral mucosa. Genital infection can be transmitted to oral mucosa through autoinoculation, oral sex, or oral contact [1,2]. The HPV related genital lesions are more frequently in adults. In Mexico, cervical-uterine cancer (CUC) is the most frequent sexually transmitted viral disease and cause of death in women older than 25 years $[3,4]$. A link between HPV and squamous cell carcinoma of the head and neck was suggested more than 20 years ago [5]. Investigators showed a strong association between high-risk HPV infection and oral squamous cell carcinoma in Mexican, Sweden Japanese, and Chinese populations [5-8]. So HPV infection is not limited to the

${ }^{*}$ Corresponding author. genital tract; it can extend to extragenital sites and particularly to the oral cavity, but the mechanism of infection of HPV into the oral mucosa remains unknown. Possibilities include self inoculation and/or through the practice of fellatio on HPV-positive male partners [9]. Genital HPV is the infection worldwide, detectable in approximately $40 \%$ of women under age of 25 years, and frequently in the sub-clinical form [10,11]. As a consequence, there are high rates of HPV infected, healthy and sexually active women, who will contribute significantly to horizontal transmission of the virus, also including transmission via the oral cavity [12-14].

More than 130 types of HPV have been identified according to the nucleotide sequence alignment of its open reading frames [15]. Based on their association to CUC and the lesions produced, HPV have been grouped in low (genotypes 6, 11, 42 - 44) and high (genotypes 16, 18, 31, $33,34,35,39,45,51,52,56,58,59,66,68,70)$ risk 
viruses [16-18]. The high risk HPV genotypes 16 and 18 are the most common, and have been detected in $95 \%$ of women with CUC [17]. Recent studies indicate that these two genotypes are also related with oral cancer or with neck and head cancer [2,5,19-21]. Besides, some risk factors such as smoking, alcohol consumption and sexual habits have also been associated to oral cancer [22-27]. However, the association of HPV between cervical and oral cavity remains unclear. The aim of this study was to detect the prevalence of high and low risk HPV in the oral cavity of women with cervical HPV and to evaluate the risk factors which contribute to its occurrence.

\section{Materials \& Methods}

\subsection{Study Participants}

We studied 18 women, aged between 24 and 52 years, who came to the Gynecology and Obstetrics Services of the Hospital Español with background of genital infection by HVP, and with clinically normal oral mucosa.

Smears of eighteen patients positive to HPV-DNA at the cervix with clinical and histopathology confirmation of high-grade squamous intraepithelial lesion were taken. Ten out of eighteen patients had previous treatment with cryotherapy between November 1991 to February 2006, and eight women were newly diagnosed with HPV. Cryotherapy was performed in ten patients using a single freeze technique with nitrous oxide as refrigerant, and it was applied to the cervix. The details of the study were explained to all participants and also an informed consent was provided before entering into the study. Information on age, education, smoking/alcohol drinking habits and sexual behavior was collected. A questionnaire was applied to gather information on personal and clinical data to determine some risk factors.

\subsection{Sampling}

Two samples were taken per patient. Cervical cells were obtained by using Ayre's spatula and an endocervical cytobrush, oral samples were collected by brushing (Oral CDX; CDx Labs). Ten complete backward and forward brushes at each oral site (upper and lower gum, cheeks, and dorsum of tongue) were performed. The brush was squeezed immediately into the side of a tube containing 1 $\mathrm{ml}$ of cold phosphate-buffered saline solution stored at $-20^{\circ} \mathrm{C}$ until use. After collection, both cervical and oral specimens were centrifuged at $2000 \mathrm{~g} \times 10 \mathrm{~min}$ and washed with saline solution, centrifuged at 12,000 $\mathrm{g} \times 10$ min, and the pellet stored at $-20^{\circ} \mathrm{C}$.

\subsection{DNA Extraction}

For DNA extraction, samples were centrifuged at $2000 \times$ $\mathrm{g}$ for $10 \mathrm{~min}$ and DNA was extracted from the pellets using the QIAamp DNA Mini kit (Qiagen Maryland, USA), according to the manufacturer's instructions. To adsorb the nucleic acids of DNA a silica-gel column containing buffer of (10 mM Tri-HCl; $0.5 \mathrm{mM}$ EDTA), and stored at $-70^{\circ} \mathrm{C}$ until used.

\subsubsection{Detection of HPV by Polymerase Chain Reaction (PCR)}

In order to identify HPV-DNA of high or low oncogenic potential, we utilized two consensus sequence primer pairs within the E6 and E7 open reading frames (ORF) to amplify HPV DNA [28]. Each $100 \mu \mathrm{l}$ polymerase chain reaction (PCR) contained 10× PCR buffer with $\mathrm{KCl}$, $\left(\mathrm{NH}_{4}\right)_{2} \mathrm{SO}_{4}, 25 \mathrm{mM} \mathrm{MgCl} 2,10 \mathrm{mM}$ dNTP, $2.5 \mathrm{U}$ Taq DNA Polymerase (Advance Biotechnologies Ltd.), $100 \mu \mathrm{M}$ of the primers and $5 \mu \mathrm{l}$ of the DNA sample. Amplifications were carried out in a DNA thermal cycler (Perkin Elmer, Norwalk, USA), using the following conditions: One cycle of initial denaturation at $95^{\circ}$ for $5 \mathrm{~min} ; 35$ amplification cycles; $94^{\circ} \mathrm{C}(40 \mathrm{~s}), 55^{\circ} \mathrm{C}(40 \mathrm{~s}), 72^{\circ} \mathrm{C}(40 \mathrm{~s})$, and polymerisation extension at $72^{\circ} \mathrm{C}$ for $7 \mathrm{~min}$.

DNA from HeLa and CaSki cells was used as positive controls of high risk, and DNA genotype 6 as low risk control. And as negative control DNA from HEp-2 cells or distilled water instead of DNA was used. All controls were obtained from the American Type Culture Collection (ATCC) and glyceraldehyde-3-phosphate dehydrogenase (GAPDH), was used as internal control. PCR samples was separated by electrophoresis in a $2 \%$ agarose gel (Sigma-Aldrich) containing ethidium bromide (Sig$\mathrm{ma}$ ), and the gels were visualized under UV light with a transiluminator (UltraLum, California, USA).

\subsubsection{Polymerase Chain Reaction Primers}

The following primers was used to identify HPV-DNA; 1ul $(100 \mu \mathrm{M}) \mathrm{HPV}$ high risk sense: (5'-TGT-CAA-AAACCG-TTG-TGT-CC-3'); HPV-DNA high risk antisense: of $1 \mathrm{ul}(100 \mu \mathrm{M})$; (5'-TGC-TAA-TTC-GGT-GCT-ACCTG-3');

HPV low risk sense: 1 ul (100 uM) (5'-GAG-CTGTCG-CTT-AAT-TGC-TC-3'), HPV low risk antisense: 1ul $(100 \mu \mathrm{M})\left(5^{\prime}\right.$-TGC-TAA-TTC-GGT-GCT-ACC-TG -3 ') [28].

\subsection{Statistical Analysis of Risk Factors}

The association between HPV infection and potential risk factors (smoking/drinking habits and oral sex) was evaluated with Chi square test/Fisher's exact test with software GraphPad Prism 5. The predetermined level of significance was $\mathrm{p}<0.05$.

\section{Results}

The study group comprised 18 women (mean age: 36 
years; range: 20 - 53 years) with cervical HPV infection.

The analysis of HPV-DNA specimens are shown in Figure 1. HPV-DNA was detected in 12/18 (67\%) of the participants, in both oral and cervical cavities. The frequency of oral and cervical low and high risk HPV-DNA in the eighteen participants shows that $9 / 18(50 \%)$ had low risk HPV-DNA in oral and cervical cavities, while high risk HPV-DNA was detected in 3/18 (17\%) and 7/18 (39\%), respectively (Figure 2).

In the oral and cervical cavities of the eighteen patients low HPV-DNA was detected in 8/18 (44\%); high risk HPV in both cavities $2 / 18(11 \%)$; in the cervix of one patient $1 / 18(6 \%)$ was detected either low and high risk HPV-DNA, whereas, one patient exhibited high risk HPV-DNA in the oral cavity $(6 \%)$ but not in cervix; and in $3 / 18(17 \%)$ was detected only high risk HPV-DNA in the cervix not in the oral cavity (Figure 3 ). Figure 4 shows the clinical history of the 18 patients included in the study. Ten out of eighteen were treated with cryotherapy (56\%); HPV-DNA was detected in 7/10 (39\%); HPV-DNA was

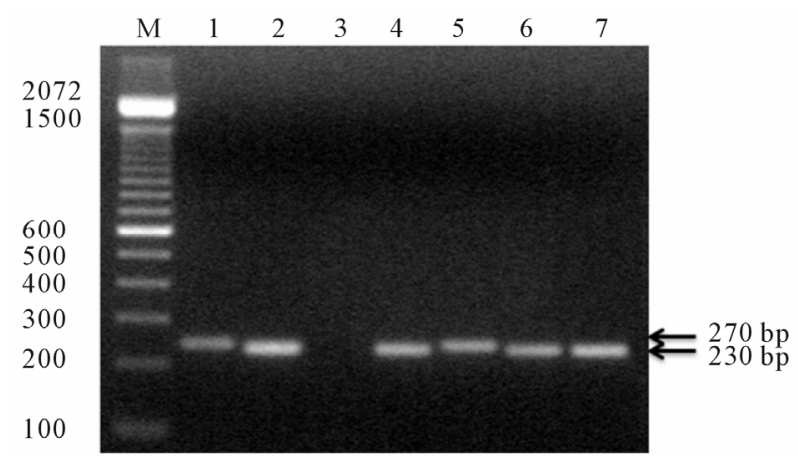

Figure 1. Agarose gel electrophoresis of amplified PCR products of HPV-DNA of oral cavity and cervix, amplicons are indicated on the gel. $\mathrm{M}=\mathrm{Mr}(100 \mathrm{bp}$ ladder $) 1$. Control of HPV high risk (Hela cells) $270 \mathrm{bp}$; 2. Control of HPVDNA 6 (230 bp); 3. Negative control no DNA; 4. Specimenes obtained from patient 5 HPV-DNA low risk; 5. Specimenes obtained from patient 5 HPV-DNA high risk; 6. HPV-DNA Low risk in patient 8; 7. HPV-DNA low risk patient 11.

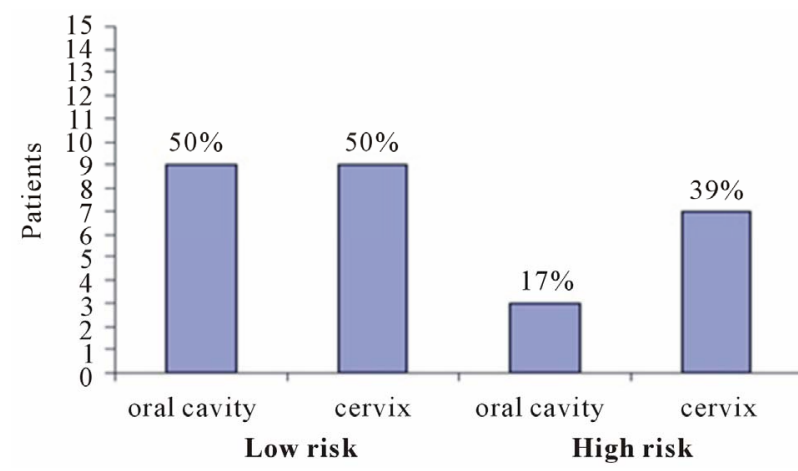

Figure 2. Frequency of low and high HPV-DNA in oral cavity and in cervix. HR, high risk; LR low risk (oc = oral cavity; $\mathbf{c x}=$ cervix).

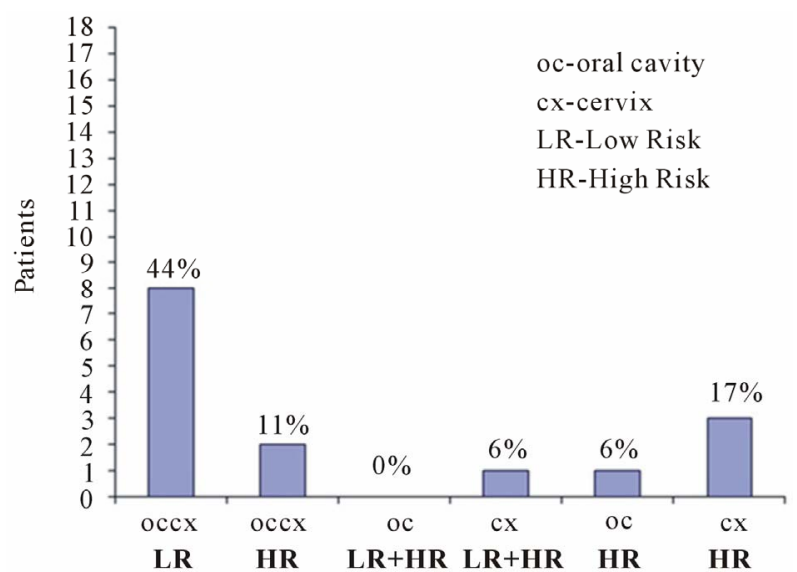

Figure 3. Presence of the HPV-DNA low and high risk binomial (oral cavity-cervix), or in a single cavity.

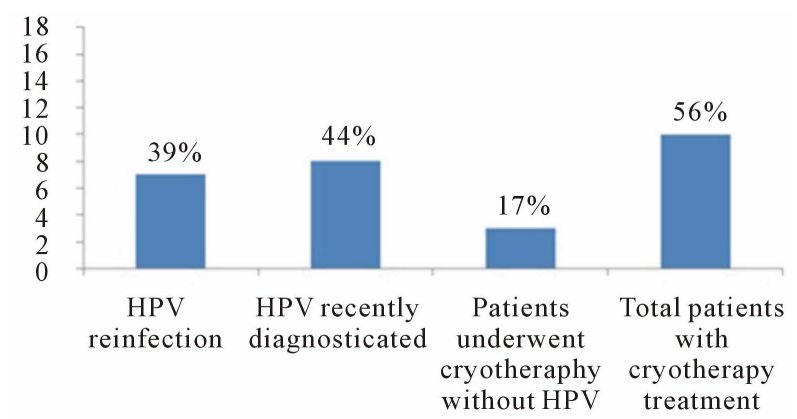

Figure 4. Clinical history of the 18 patients included in the study.

not detected in 3/18 (17\%) neither oral cavity nor cervix; and 8/18 (44\%) were newly HPV-DNA diagnosed.

The analysis of smoking/alcohol drinking/sex habits in the eighteen patients showed that $7 / 18(39 \%)$ presented smoking habit; 5/18 (28\%) alcohol drinking habit; 14/18 $(78 \%)$ practiced oral sex $(\mathrm{p}<0.02)$. Regarding the participants age we observed that the most affected group with HPV-infection was the age group between 42 - 53 . Table 1. The results of the analysis of the oral sex habit showed that $10 / 18(56 \%)$ had HPV-DNA in oral cavity and in cervix. On the other hand, the analysis of the smoking/alcohol drinking/sex habits in the 7 patients that had been treated with cryotherapy showed that 6/7 (60\%) practiced oral sex; $2 / 7$ (20\%) had alcohol drinking habit; and 3/7 (30\%) had the smoking habit (Figure 5).

\section{Discussion}

Molecular, clinical and epidemiological studies have verified that the HPV is the main etiological agent of CUC [11, 27-30]. HPV infections represent one of the most common sexually transmitted viral diseases with frequencies going from $30 \%$ to $50 \%$ in sexually active women [31]. The prevalence of HPV in oral cavity of women with cervical HPV was high $67 \%$, we detected both low and high risk 
Table 1. Distribution of low and high risk HPV-DNA in oral cavity and cervix stratified by group age, sex habits, smoking and alcohol drinking.

\begin{tabular}{|c|c|c|c|c|c|c|}
\hline Group age & Patients & Oral cavity & Cervix & Smoking habit & Alcoholism & Oral sex \\
\hline $20-25$ & 1 & HR & HR & Positive & Positive & Positive \\
\hline \multirow[t]{2}{*}{$26-30$} & 1 & Negative & HR & Negative & Negative & Negative \\
\hline & 2 & LR & LR & Negative & Negative & Positive \\
\hline \multirow[t]{7}{*}{$31-35$} & 1 & Negative & HR & Negative & Negative & Positive \\
\hline & 2 & HR & LR & Positive & Positive & Positive \\
\hline & 3 & Negative & Negative & Negative & Negative & Positive \\
\hline & 4 & LR & LR & Positive & Negative & Positive \\
\hline & 5 & Negative & Negative & Positive & Positive & Positive \\
\hline & 6 & LR & LR & Negative & Positive & Negative \\
\hline & 7 & HR & HR & Negative & Positive & Negative \\
\hline \multirow[t]{2}{*}{$36-41$} & 1 & LR & HR & Negative & Negative & Positive \\
\hline & 2 & Negative & Negative & Negative & Negative & Positive \\
\hline \multirow[t]{3}{*}{$42-47$} & 1 & LR & LR & Negative & Negative & Positive \\
\hline & 2 & LR & LR & Negative & Negative & Positive \\
\hline & 3 & LR & LR & Positive & Negative & Positive \\
\hline \multirow[t]{3}{*}{$48-53$} & 1 & Negative & HR & Negative & Negative & Negative \\
\hline & 2 & LR & $\mathrm{LR} / \mathrm{HR}$ & Positive & Negative & Positive \\
\hline & 3 & LR & LR & Positive & Negative & Positive \\
\hline \multirow[t]{3}{*}{ Total } & 18 & & & & & \\
\hline & \multicolumn{2}{|c|}{ Positive (Habits) } & & $\begin{array}{l}7 / 18 \\
39 \%\end{array}$ & $\begin{array}{l}5 / 18 \\
28 \%\end{array}$ & $\begin{array}{c}14 / 18 \\
78 \%\end{array}$ \\
\hline & \multicolumn{2}{|c|}{ Negative } & & $\begin{array}{c}11 / 18 \\
61 \%\end{array}$ & $\begin{array}{c}13 / 18 \\
72 \%\end{array}$ & $\begin{array}{l}4 / 18 \\
22 \%\end{array}$ \\
\hline
\end{tabular}

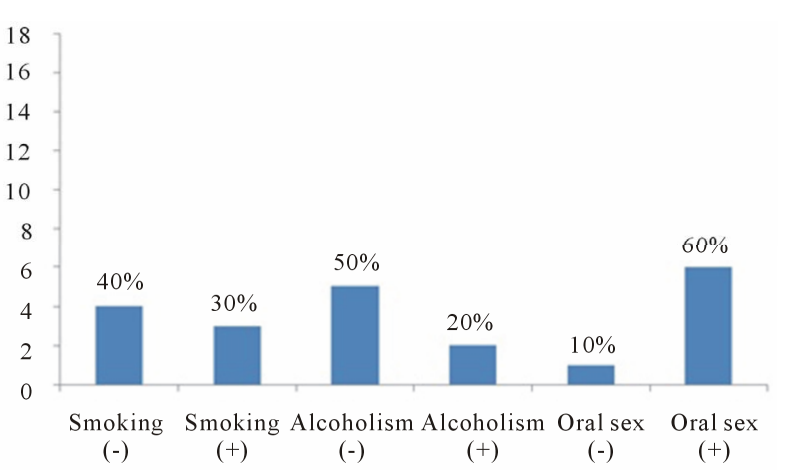

Figure 5. Analysis of risk factors in women with HPV-reinfection.

\section{HPV-DNA virus.}

The results of our study showed that high risk HPVDNA was more prevalent in the cervix of women $39 \%$, whereas oral high risk HPV-DNA was detected only in $17 \%$. A predominance of low risk HPV-DNA in oral cavity and cervix (50\%) was observed (Figure 2).

A study was conducted to determine the HPV prevalence and concurrent infection in the cervix and oral cavity of 577 pregnant women, found $29 \%$ positivity in the cervix and $2.4 \%$ positivity in the oral cavity. No association was found between HPV positivity and its types detected in the cervix and oral cavity of these women, suggesting the author that self- inoculation was uncommon [32-34].

The finding that the high risk HPV-DNA in oral cavity was found in less proportion (17\%) than in cervix (39\%) could have the follow explanation (Figure 2). Although oral cavity is in direct contact with carcinogens present in tobacco and alcohol, making them the primary cause of oral carcinogenesis, this is not the case with cervical re- 
gion, where there is no direct contact with this carcinogens but the cervical region does not have saliva, that oral cavity does. The low prevalence of oral HPV infection might be due to the body's immune response, like immunoglobulin IgA and proteolytic enzymes in the saliva that protect the oral mucosa from viral infections like cystatins, mucins serin-proteases inhibitors, and VonEbner proteins [35]. Antibodies produced in response to initial infection, in this case cervical infection, might as well protect the body against further infections by the same virus on other sites. Although the oral mucosa epithelium resembles the epithelium of the genital tract [36], antimicrobial action of saliva, along with its cleansing and lubricating properties, may reduce the possibility of virus entry into the oral epithelial cells by reducing the contact period of the virus with the oral mucosa [35-37]. These important factors could contribute to prevent the establishment of a high risk HPV in the oral mucosa.

Our results showed that the higher of HPV positivity was in the oldest group age participants (43 to 53 years) was infected with low risk and high risk HPV, this could be explained partially because the infection with high risk genotypes (16 and 18) involves factors that influence the acquisition and progression of the injury degrees caused by HPV infection, the most common ones are: early start of sexual activity, the number of sexual encounters (in women with only one partner, HPV is observed in $17 \%$ to $21 \%$ and increases to $69 \%-83 \%$ in those with more than five sexual partners), an inadequate immune response, hormonal action (including the prolonged use of oral anticonceptives associated with a higher susceptibility to malignant progression), nutritional deficiencies, other sexually transmitted infections, and genetic predisposition (haplotypes of the major histocompatibility system associated to a greater susceptibility to malignant progression) [35-39]. Other possibility is that this finding could be the result of an accumulated lifetime exposure to the viruses, with the added risk of sexual activity. In this work the statistical analysis of risk factors showed that oral sex habit $(\mathrm{p}<0.02)$ is a dependent variable that could promote the HPV establishment in the oral cavity, so these data suggest that oral cavity may be a reservoir of HPV in these patients. In our study we found that the oral sex habit was present in the oral cavity of women with cervical HPV ( $p$ $<0.02$ ), if subjects with cervical HPV practice oral sex, then HPV could be established in the oral cavity with any problem.

Our results showed a high prevalence from $78 \%$ (14/18) of oral sex habits, so probably this risk factor could be relevant in the Mexican population, but it has to be analysed a higher number in order to conclude the importance of the oral sex habit in the HPV transmission. Interestingly, 7 out of 10 patients treated with cryotherapy between November 1991 to February 2006 and HPV-
DNA positive at the moment of the study, present the oral sex habit $6 / 7$ (60\%) so it could be important to determine if the oral cavity is an important reservoir for reinfections or cryotherapy is not an adequate treatment to eliminate HPV.

On the other hand, studies have shown that smoking has potential to alter oral epithelium, thus it has and influence on HPV expression in oral cavity [40]. Cigarette smoking, in combination with HPV oncogenic types, is strongly associated with risk of cervical dysplasia [41,42]. Smoking also increases the risk of oral and pharyngeal cancer [39-42]. Given the apparent association between oral cancer and HPV infection and given the association between smoking and oral cancer, we examine the association between HPV infection and smoking. We were able to detect HPV-DNA infection from $39 \%$ of the participants that had the smoking habit, and it is well known that alcohol increases the permeability of the mucous membranes inducing local immunosuppression and thereby facilitating HPV infection [42-45]. In our study the $28 \%$ of the participants had the alcohol drinking habit.

D'Souza et al. [46] demonstrate that oral sexual behaviours are associated with the detection of prevalent oral HPV, with this study the investigators have taken an additional step toward improving our understanding of the epidemiological profile of oral HPV transmission.

It has been theorized that oral infections are likely the result of oral-genital contact. The present study suggests and could expands on that theory by demonstrating that not only are oral-sexual behaviours important, but more common habits, such as smoking or drinking alcohol, may also contribute to the HPV infection to the oral region. It could be interesting to evaluate whether the oral cavity could be not only the reservoir for HPV, but for other pathogens [47]. The results of the present investigation showed a high frequency of HPV $(67 \%)$ infection in the oral and genital mucosas, suggesting that patient's habits could contribute to the infection; and they suggest that the mode of viral transmission. The presence of HPV in the oral mucosa may act as reservoir for new HPV infections and /or as sources of recurring HPV lesions, as has been observed with other microorganisms.

\section{Acknowledgements}

Funding: This work was supported by the Departamento de Microbiología y Parasitología, Facultad de Medicina UNAM and the Instituto Nacional de Enfermedades Respiratorias (INER).

The Ethical Approval was given by the Ethics committee of the INER with the reference number C54-11.

\section{REFERENCES}

[1] M. Cañadas, F. Bosch, M. Junquera, M. Ejarque, R. Font, 
E. Ordoñez and S. de Sanjosé, "Concordance of Prevalence of Human Papillomavirus DNA in Anogenital and Oral Infections in a High-Risk Population," Journal of Clinical Microbiology, Vol. 42, No. 3, 2004, pp. 13301332.

[2] J. Baseman and L. Kuotsky, "The Epidemiology of Human Papillomavirus Infections," Journal of Clinical Virology, Vol. 32, 2005, pp. 16-24. doi:10.1016/j.jcv.2004.12.008

[3] A. Hidalgo-Martìnez, "El Cáncer Cérvico-Uterino, su Impacto en Mèxico y el porqué no Funciona el Programa Nacional de Detección Oportuna," Revista Biomédica, Vol. 17, No. 1, 2006, pp. 81-84.

[4] INEGI, "Secretaría de Salud," Dirección General de Información en Salud con Base en Datos de Defunciones, México City, 2005.

[5] M. Manjarrez, R. Ocadiz, L. Valle, C. Checo, A. Marroquin, C. de la Torre, M. Selman and P. Gariglio, "Detection of Human Papillomavirus and Relevant Tumor Supressors and Oncoproteins in Laryngeal Tumors," Clinical Cancer Research, Vol. 12, No. 23, 2006, pp. 69466951. doi:10.1158/1078-0432.CCR-06-1214

[6] K. Kurose, M. Terai, N. Soedarsono, D. Rabello, Y. Nakajima, R. Burk and M. Takagi, "Low Prevalence of HPV Infection and Its Nature History in Normal Oral Mucose among Volunteers on Miyako Island Japan," Oral Surgery, Oral Medicine, Oral Pathology, Oral Radiology \& Endodontics, Vol. 98, No. 1, 2004, pp. 91-96. doi:10.1016/i.tripleo.2003.12.029

[7] K. Uobe, K. Masuno Y. Fang, L. Li, Y. Wen and Y. Ueda, "Detection of HPV in Japanese and Chinese Oral Carcinoma by in Situ PCR," Oral Oncology, Vol. 37, No. 2, 2001, pp. 146-152. doi:10.1016/S1368-8375(00)00075-0

[8] J. Kello, S. Syrjänen, M. Yliskoski and K. Syrjänen, "Dot Blot Hybridization in Detection of Human Papillomavirus (HPV) Infections in the Oral Cavity of Women with Genital HPV Infections," Oral Microbiology and Immunology, Vol. 7, No. 1, 1992, pp. 19-23. doi:10.1111/j.1399-302X.1992.tb00014.X

[9] P. Castle, "Human Papillomavirus in Oral Exfoliated Cells and Risk of Head and Neck Cancer," Journal of the National Cancer Institute, Vol. 96, No. 15, 2004, pp. 1181-1183.

[10] F. Bosch, M. Manos, N. Muñoz, M. Sherman, A. Jansen, J. Peto, M. Schiffman, V. Moreno, R. Kurman and K. Shah, "Prevalence of Human Papillomavirus in Cervical Cancer: A Worldwide Perspective; International Biological Study on Cervical Cancer (IBSCC) Study Group," Journal of the National Cancer Institute, Vol. 87, No. 11, 1995, pp. 796-802. doi:10.1093/jnci/87.11.796

[11] M. Schiffman, H. Bauer and R. Hoover, "Epidemiologic Evidence Showing That Human Papillomavirus Infection Causes Most Cervical Intraepithelial Neoplasia," Journal of the National Cancer Institute, Vol. 85, No. 11, 1993, pp. 958-964. doi:10.1093/jnci/85.12.958

[12] S. M. Schwartz, J. R. Daling, D. R. Doody, G. C. Wipf, J. J. Carter, M. M. Madeleine, E. J. Mao, E. D. Fitzgibbons, S. Huang, A. M. Beckmann, J. K. McDougall and D. A. Galloway, "Oral Cancer Risk in Relation to Sexual His- tory and Evidence of Human Papillomavirus Infection," Journal of the National Cancer Institute, Vol. 90, No. 21, 1998, pp. 1626-1636. doi:10.1093/jnci/90.21.1626

[13] S. Nair and M. Pillai, "Human Papillomavirus and Disease Mechanisms: Relevance to Oral and Cervical Cancers," Oral Diseases, Vol. 11, No. 6, 2005, pp. 350-359. doi:10.1111/j.1601-0825.2005.01127.x

[14] P. Giraldo, A. Goncalves S. Pereira, S. Barros-Mazon, M. Gondo and S. Witkin, "Human Papillomavirus in the Oral Mucosa of Women with Human Papillomavirus Lesions", European Journal of Obstetrics \& Gynecology and Reproductive Biology, Vol. 126, No. 1, 2006, pp. 104-106.

[15] E. de Villers, C. Fauquet, T. Broker, H. Bernand and Z. Hausen, "Classification of Papillomaviruses," Virology, Vol. 324, No. 1, 2004, pp. 17-27. doi:10.1016/j.virol.2004.03.033

[16] M. Conway and C. Meyers, "Replication and Assembly of Human Papillomavirus," Journal of Dental Research, Vol. 88, No. 4, 2009, pp. 307-317. doi: $10.1177 / 0022034509333446$

[17] E. Burd, "Human Papillomavirus and Cervical Cancer," Clinical Microbiology Reviews, Vol. 16, No. 1, 2003, pp. 1-17. doi:10.1128/CMR.16.1.1-17.2003

[18] D. Chang, C. Hsieh, R. Chen, S. Lee and S. Huang, "Comparison of Detection of Human Papillomavirus 16 DNA in Cervical Carcinoma Tissues and Southern Blot Hybridisation and Nested Polymerase Chain Reaction," Journal of Medical Microbiology, Vol. 43, No. 6, 1995, pp. 430-435. doi:10.1099/00222615-43-6-430

[19] S. Begum, M. Guillison, T. Nico and W. Westra, "Detection of Human Papillomavirus 16 in Fine-Needle Aspirates to Determine Tumor Origin in Patients with Metastatic Squamous Cell Carcinoma of the Head and Neck," Clinical Microbiology Reviews, Vol. 13, No. 4, 2007, pp. 1186-1191. doi:10.1158/1078-0432.CCR-06-1690

[20] P. Castle, "Human Papillomavirus in Oral Exfoliated Cells and Risk of Head and Neck Cancer," Journal of the National Cancer Institute, Vol. 96, No. 15, 2004, pp. 1181-1183. doi:10.1093/jnci/djh232

[21] T. Castro and I. F. Bussoloti, "Prevalence of Human Papillomavirus (HPV) in Oral Cavity and Oropharynx," Revista Brasileira de Otorrinolaringologia, Vol. 72, No. 2, 2006, pp. 272-282. doi:10.1590/S0034-72992006000200021

[22] G. D’Souza, A. Kreimer, R. Viscidi, M. Pawlita, C. Fakhry, W. Koch, W. Westra and M. Guillison, "Case-Control Study of Human Papillomavirus and Oropharyngeal Cancer," The New England Journal of Medicine, Vol. 356, No. 19, 2007, pp. 1944-1956. doi:10.1056/NEJMoa065497

[23] C. Furniss, M. McClean, J. Smith, J. Bryan, K. Applebaum, H. Nelson, M. Posner and K. Kelsey, "Human Papillomavirus 6 Seropositivity Is Associated with Risk of Head and Neck Squamous Cell Carcinoma, Independent of Tobacco and Alcohol Use," Annals of Oncology, Vol. 20, No. 3, 2009, pp. 534-541. doi:10.1093/annonc/mdn643

[24] L. Giovannelli, G. Campisi, A. Lama, O. Giambalvo, J. Osborn, V. Margiotta and P. Ammatuna, "Human Papil- 
lomavirus DNA in Oral Mucosal Lesions," The Journal of Infectious Diseases, Vol. 185, No. 6, 2002, pp. 833836. doi: $10.1086 / 339193$

[25] D. Hennessey, W. Westra and J. Califano, "Human Papillomavirus and Head and Neck Squamous Cell Carcinoma: Recent Evidence and Clinical Implications," Journal of Dental Research, Vol. 88, No. 4, 2009, pp. 300-306. doi:10.1177/0022034509333371

[26] C. Fakhry, G. D’Souza, E. Sugar, K. Weber, E. Goshu, H. Minkoff, R. Wright, E. Seaberg and M. Guillison, "Relationship between Prevalent Oral and Cervical Human Papillomavirus Infections in Human Immunodeficiency Virus-positive and-negative Women," Journal of Clinical Microbiology, Vol. 44, No. 12, 2006, pp. 4479-4485. doi:10.1128/JCM.01321-06

[27] J. Walboomers, M. Jacobs M. Manos, F. Bosch, J. Kummer, K. Shah, P. Snijders, J. Peto, C. Meije and N. Munoz, "Human Papillomavirus Is a Necessary Cause of Invasive Cervical Worldwide," Journal of Pathology, Vol. 189, No. 1, 1999, pp. 12-19.

doi:10.1002/(SICI)1096-9896(199909)189:1<12::AID-P ATH431>3.0.CO;2-F

[28] Y. Fujinaga, M. Shimada, K. Okasawa, M. Fukushima, I. Kato and K. Fujinaga, "Simultaneous Detection and Typing of Genital Human Papillomavirus DNA Using the Polymerase Chain Reaction," Journal of General Virology, Vol. 72, No. 5, 1991, pp. 1039-1044.

[29] F. Bosch, A. Lorincz, N. Muñoz, C. Meijer and K. Shah, "The Causal Relation between Human Papillomavirus and Cervical Cancer," Journal of Clinical Pathology, Vol. 55, No. 4, 2002, pp. 244-265. doi:10.1136/jcp.55.4.244

[30] M. Schiffman, H. Bauer and R. Hoover, "Epidemiologic Evidence Showing That Human Papillomavirus Infection Causes Most Cervical Intraepithelial Neoplasia," Journal of the National Cancer Institute, Vol. 85, No.12, 1993, pp. 958-964. doi:10.1093/jnci/85.12.958

[31] N. Termine, L. Giovannelli, S. Matranga, A. Perino, V. Panzarella, P. Ammatuna, M. D’Angelo and G. Campisi, "Low Rate of Oral Human Papillomairus (HPV) Infection in Women Screened for Cervical HPV Infection in Southern Italy: A Cross-Sectional Study of 140 Immunocompetent Subjects," Journal of Medical Virology, Vol. 81, No. 8,2009, pp. 1438-1443. doi:10.1002/jmv.21509

[32] G. D'Souza, E. Sugar, W. Ruby, P. Gravitt and M. Guillison, "Analysis of the Effect of DNA Purification on Detection of Human Papillomavirus in Oral Rinse Samples by PCR," Journal of Clinical Microbiology, Vol. 43, No. 11, 2005, pp. 5526-5535. doi:10.1128/JCM.43.11.5526-5535.2005

[33] E. Smith, J. Ritchie, J. Yankowitz, D. Wang, L. Turek and T. Haugen, "HPV Prevalence and Concordance in the Cervix and Oral Cavity of Pregnant Women," Infectious Diseases in Obstetrics and Gynecology, Vol. 12, No. 2, 2004, pp. 45-56. doi:10.1080/10647440400009896

[34] E. Franco, E. Duarte-Franco and A. Ferenczy, "Cervical Cancer: Epidemiology, Prevention and Role of Human Papillomavirus Infection," Canadian Medical Association Journal, Vol. 164, No. 7, 2001, pp. 1017-1025.

[35] D. Miletic, S. Schiffman, V. Miletic and E. Miller, "Sali- vary IgA Secretion Rate in Young and Elderly Persons," Physiology \& Behavior, Vol. 60, No. 1, 1996, pp. 243248. doi:10.1016/0031-9384(95)02161-2

[36] I. Thompson, P. van der Bijl, C. van Wyk and A. van Eyk, "A Comparative Light Microscopic, Electron-Microscopic and Chemical Study of Human Vaginal and Buccal Epithelium," Archives of Oral Biology, Vol. 46, No. 12, 2001, pp. 1091-1098. doi:10.1016/S0003-9969(01)00082-6

[37] J. Cervantes, “Aspectos Inmunológicos de la Infección por Papilomavirus Humano. Rol del Complejo Mayor de Histocompatibilidad," Revista Medica Herediana, Vol. 14, No. 2, 2003, pp. 94-98.

[38] L. Guzmán-Rojas, J. Alcocer-González and V. MadrirMarina, "Perspectivas Para el Desarrollo de Vacunas e Inmunoterapia Contra el Cáncer Cervicouterino," Salud Pública de México, Vol. 40, No. 1, 1998, pp. 38-46 doi:10.1590/S0036-36341998000100006

[39] K. Syrjanen, "HPV Infections and Esophageal Cancer," Journal of Clinical Pathology, Vol. 55, No. 10, 2002, pp. 721-728. doi:10.1136/jcp.55.10.721

[40] C. Roteli-Martins, K. Panetta, V. Alves, S. Siqueira, K. Syrjanen and S. Derchain, "Cigarrete Smoking and High Risk HPV-DNA as Predisposing Factors for High-Grade Cervical Intraepithelial Neoplasia (CIN) in Young Brazilian Women," Acta Obstetricia et Gynecologica Scandinavica, Vol. 77, No. 6, 1998, pp. 678-682. doi:10.1034/j.1600-0412.1998.770617.x

[41] A. Olsen, J. Dillner, A. Skrondal and P. Magnus, "Combined Effect of Smoking and Human Papillomavirus Type 16 in Cervical Carcinogenesis," Epidemiology, Vol. 9, No. 3, 1998, pp. 346-349. doi:10.1097/00001648-199805000-00022

[42] F. Lewin, S. Norell, H. Johansson, P. Gastavsson, J. Wennerberg, A. Bioklund and E. Rutqvist-Lars, "Smoking Tabacco, Oral Snuff, and Alcohol in the Etiology of Squamous Cell Carcinoma of the Head and Neck: A Population-Based Case-Referent Study in Sweden," Cancer, Vol. 82, No. 7, 1998, pp.1367-1375. doi:10.1002/(SICI)1097-0142(19980401)82:7<1367::AID -CNCR21>3.0.CO;2-3

[43] S. M. Schartz, J. R. Daling, D. R. Doody, G. C. Wipf, J. J. Carter, M. Madeleine, E.-J. Mao, E. D. Fitzgibbons, S. Huang, A. M. Beckmann, J. McDougall and D. Galloway, "Oral Cancer and Risk in Relation to Sexual History and Evidence of Human Papillomavirus Infection," Journal of the National Cancer Institute, Vol. 90, No.21, 1998, pp. 1626-1636. doi:10.1093/jnci/90.21.1626

[44] E. Smith, M. H. Hoffman, K. Summersgill, H. Kirchnner, L. P. Turek and T. Haugen, "Human Papillomavirus and Risk of Oral Cancer," Laryngoscope, Vol. 108, No. 7, 1998, pp. 1098-1103. doi:10.1097/00005537-199807000-00027

[45] E. Ringstrom, E. Peters, M. Hasegawa, M. Posner, M. Liu and K. Kelsey, "Human Papillomavirus Type 16 and Squamous Cell Carcinoma of the Head and Neck," Clinical Cancer Research, Vol. 8, No. 10, 2002, pp. 3187 3192.

[46] G. D'Souza, Y. Agrawal, J. Halpern, S. Bodison and M. 
Gillison, "Oral Sexual Behaviours Associated with Prevalent Oral Human Papillomavirus Infection," Journal of Infectious Diseases, Vol. 199, No. 9, 2009, pp. 1263-1269. doi: $10.1086 / 597755$

[47] R. Morales-Espinoza, A. Fernández-Presas, G. GonzálezValencia, G. Delgado, J. L. Méndez-Sánchez, S. Flores-
Hernández, E. Sánchez-Quezada, L. Muñoz-Pérez, R. Léon-Aguilar, J. Hernández-Guerrero and A. Cravioto, "Helicobacter pylori Detection in the Oral Cavity Is Strongly Associated with Gastroesophageal Disease," Oral Microbiology and Immunology, Vol. 24, No. 6, 2009, pp. 464-468. doi:10.1111/j.1399-302X.2009.00541.X 